\title{
Effect of Content Knowledge on Scientific Argumentation Quality: Cloning Context
}

\author{
Ali Yiğit KUTLUCA ${ }^{1, *}$, Pınar Seda Çetin², \& Nihal Doğan² \\ ${ }^{1}$ Kastamonu University, Kastamonu, TURKEY; ${ }^{2}$ Abant İzzet Baysal \\ University, Bolu, TURKEY
}

Received: 06.09.2013

Accepted: 18.04 .2014

\begin{abstract}
Argumentative discourse in classrooms is given much importance by science educators due to its potential contributions to teachers' general pedagogical knowledge of teaching higher order thinking skills and strategies as well as its learner-centered nature. For this reason, the present study searched for a possible link between pre-service teachers' domain-specific knowledge and the quality of their argumentations. For data collection, Lyngved's (2009) ‘Cloning Conceptual Understanding Exam' (CCUE) was administered to PSTs. Given the results of the CCUE, the PSTs (44 female and 10 male) were divided into three cohort groups as high, middle, and low-achievers. Further, semi-structured interviews were conducted with three PSTs. They were exposed to three (controversial) cloning scenarios and asked to constitute scientific argumentations. The argumentations generated by the PSTs were qualitatively analyzed using an analytical assessment tool by Erduran, Simon, and Osborne (2004). The results showed no straightforward relationship between the PSTs' content knowledge and the quality of their argumentation. The findings concerning the link between content knowledge and argumentation quality were discussed. Further studies could look at the relationship between content knowledge and argumentation quality with a different subject matter and larger-sized samples.
\end{abstract}

Key words: argumentation, scientific argumentation, content knowledge, cloning.

\section{DOI No: 10.12973/nefmed.2014.8.1.a1}

\section{Introduction}

Nowadays, scientific literacy is considered to be one of the most significant issues by many of educational systems throughout the world (AAAS, 2000). Scientifically literate individuals are expected to be able to adapt to fast-developing scientific and technological changes. Therefore, paving the way for future generations as better civilizations with such individuals is one of the broader goals of science education. In this context, in many

\footnotetext{
*Corresponding Author: Ali Yigit KUTLUCA, Faculty of Education, Kastamonu University, Kastamonu, TURKEY

E-mail: aliyigit8834@gmail.com
} 
countries, contemporary science curriculum studies have acknowledged that science education has an important place in terms of putting the contemporary educational goals, and scientific literacy in particular, into practice (Council of Ministers of Education, Canada, 1997; Curriculum Council of Western Australia, 1998).

Critical thinking and inquiry have a major role in line with the contemporary goals of science education. Engaging in scientific argumentation, then becomes important in science education as a suitable pedagogical tool in carrying out the above-mentioned goals and in teaching the processes in which scientists construct and articulate scientific theories (Erduran, 2007). Argumentation, as Kuhn (1993) states, is a dialogical discussion with two or more individuals involved, which is based on arguing both competing and alternative claims in the same context. Argumentation can be handled in two ways: firstly, rhetorical argumentation is a process in which individuals present propositions to a specific claim or generate justifications about a discussion topic. Secondly dialogical (dialectical) or multi-voiced argumentation is a process in which different viewpoint(s) are assessed and debated regarding one or more claims in order to reach a consensus in a discussion community (Kuhn, 1993). To elaborate, Simon and Johnson (2008) state that, especially in teaching and learning science, elementary students should actively engage in scientific argumentations in order to acquire the knowledge and skills necessary to understand scientific phenomena, experiments, models, and explanations. Moreover, in these science learning processes, argumentation has a unique role as one of the purposes of scientific inquiry is to comprehend the operations for revealing natural phenomena and beliefs, and also for generating knowledge claims. In addition, most of the conceptions taught in science classes are these kinds of scientific knowledge (JimenezAleixandre, Rodriguez \& Duschl, 2000). However, argumentation is not only limited to contributing to the conceptual understanding of students. According to Bricker and Bell (2008), who define argumentation as a core practice of scientific endeavor, the goal of science education is not to train students as specialists in a specific knowledge domain, but to encourage them to engage in discourse in general and argumentation in particular in a social constructivist sense. Thus, students should be given the chance to articulate their positions in a classroom atmosphere which has to be designed from a social constructivist perspective and their argumentation should be consistent with constructivist epistemology (Erduran \& Jimenez-Aleixandre, 2007). Moreover, as many studies report, the integration of scientific argumentation into relevant learning activities can contribute to increasing scientific literacy (Driver, Newton \& Osborne, 2000; Duschl \& Osborne, 2002). According to Driver et al. (2000), teachers should provide classroom environments to let their students engage in 
argumentation to develop their conceptual qualities, investigative competence, and their understanding of the epistemology of science and of science as a social practice. It must however be kept in mind that, in the processes of argumentation, teachers do not adopt a knowledge transmission model of pedagogy, rather they adapt both themselves and their students to a pedagogy that requires knowledge construction for an argumentative classroom culture (Zohar, 2007; Erduran \& Jimenez-Aleixandre, 2007). In light of the above discussion, it can be argued that explicit engagement of PSTs in argumentative processes in which they have the opportunity to articulate their own ideas comfortably in scientific and socio-scientific contexts can enhance their general pedagogical knowledge in that they can treat argumentation as an appropriate pedagogical tool in their own classrooms. Consequently, this allows the creation of classroom climates that provide the opportunity to educate scientifically literate and more democratic individuals (Kolsto, 2001).

\section{Students' Knowledge of Content and Argumentation}

In the relevant science education literature, it is reported that the quality of argumentations generated by individuals can be affected by their social environment (Dawson \& Schibeci, 2003), their field knowledge (Roychoudhury \& Rice, 2009; Sadler \& Donnely, 2006; Sadler \& Fowler, 2006; Means \& Voss, 1996), and their teachers (Simon, Erduran \& Osborne 2006, Erduran et al., 2006). In the rest of this paper, relevant literature is discussed in terms of the link between the quality of argumentation and content knowledge. First of all, a recent study by Tavares, Jimenez-Aleixandre, and Mortimer (2010) reveals that $12^{\text {th }}$ graders' domain specific knowledge of models of the theory of evolution is a determining factor in generating higher quality scientific argumentations. Moreover, von Aufschnaiter, Erduran, Osborne, and Simon (2008) inquired how students' argumentations might relate to their prior scientific knowledge and they found that students' pre-knowledge has an incremental effect on their argumentations, and this study shows that any attempt to improve students' knowledge through argumentation is highly related to learners' prior knowledge. Also, Roychoudhury and Rice (2009) conclude in their study within the scope of a physics lecture that students' argumentation quality is positively influenced by their knowledge of physics and the quality of conceptualizations. Furthermore, Clark and Sampson (2008) propose that while conducting scientific argumentation activities the divergence of discussants, the intensity (frequency) of the discussion sessions, the ability to transfer and apply prior knowledge, and students' conceptual quality are indicative elements in detecting their argumentation quality. In a more recent study by the same researchers (Sampson \& Clark, 2011), the students were first divided 
into groups as high and low achievers according to their level of content knowledge in a specific knowledge domain. They then took part in cooperative-based scientific discussions while the researchers observed reciprocal interactions among the student groups. Finally, it was concluded that high achieving students were able to generate more extended and sophisticated argumentations compared to the low achievers, which clearly shows in their data analysis. Another study, a doctoral dissertation by Acar (2008), examining how students' argumentation quality affect their domain specific knowledge pertinent to buoyancy demonstrated that when students' knowledge begin to increase, they are able to generate more sophisticated and higher quality argumentations. Therefore, the study supports the idea that the level of prior content knowledge contributes to argumentation. Thus far, we have considered the significant contribution of content knowledge to argumentation and this is an expected assumption. Put differently, as Sadler and Donnelly (2006) point out, mastery of the required science content knowledge relevant to the topic under discussion enables people to construct higher quality argumentations compared to less-informed peers. However, there are also some contradictory findings in the literature (Sadler, 2004; Perkins, Faraday, \& Bushey, 1991; Kuhn, 1991). For example, Means and Voss (1996) argue that, even though content knowledge reveals some patterns of argumentation such as generating more knowledge claims (theory), data (evidence), and warrants (justifications), they do not guarantee articulating higher quality argumentation. Means and Voss suggest that some basic components of an argument can be seen frequently within an argumentation process, but in the absence of counterarguments, weighing and evaluating alternative points of views and rebuttals, argumentation quality would be restricted to a lower level. In a similar vein, Eskin and Bekiroglu (2009) examine the extent to which students with prior field knowledge engage in argumentation. They conclude implicitly and differently from counter-positioned studies that students' argumentation quality is not associated with their pre-existing knowledge. Very similar conclusions were reported in a more recent case study by Hakyolu and OganBekiroglu (2011).

In outlining the rationale of the current study, the relevant literature demonstrates that most studies report a positive link between the variables investigated: degree of content knowledge and its contribution to argumentation. However, it must be kept in mind that, as is also clear from our literature review, there is no consensus among scholars as regards content knowledge affecting argumentation. Also, the aforementioned studies do not present adequate explanations about whether domain specific knowledge affects argumentation in scientific contexts. Therefore, PSTs were engaged in the scientific argumentation processes within the 
scope of the present study in order to investigate the relation between the quality of their scientific argumentations about cloning and their knowledge of content. Thus, the purpose of the present study was to examine the effect of PSTs' knowledge of content about cloning on the quality of their scientific argumentations. Moreover, as an original feature of the current study, the researchers broadly investigated the socio-scientific aspects of cloning (Topcu, Sadler \& Tüzün-Y1lmaz, 2010; Venville \& Dawson, 2010; Sadler \& Fowler, 2006; Yoon, 2008). Also, these studies did not treat cloning in particular; they tended to consider it with respect to biotechnology issues.

In sum, the present study is significant firstly in investigating how the individuals' conceptual quality affects their argumentations regarding cloning and secondly in contributing to the relevant literature. The research question of the present study is whether there is a relation between PSTs' scientific argumentation quality and their conceptual understanding of cloning.

\section{Methods}

Design of the Study

The present study can be seen as a single case study in that our case presents a bound structure and we can describe it in a thick description (Creswell, 2007, p. 73). In this study, the participants were grouped according to their knowledge of content. In a 'Special Topics in Biology' course, the participants engaged in scientific argumentations concerning cloning and its medical applications. Before the argumentations, basic concepts of argumentation and its grounds were explicitly introduced to the PSTs to provide a knowledge base for them within a definite place and time.

\section{Participants}

There were 54 participants (44 female and 10 male) who were pre-service senior science teachers studying at a public university. They were divided into small discussion groups according to their scores on a conceptual understanding test on cloning as high, middle, and low achievers. These groups were homogeneous intra-groups, and were substantially heterogeneous inter-groups in the sense of the group members' pre-knowledge. The small discussion groups were arranged based on maximum variation sampling strategy (Patton, 1990). The rationale in forming small discussion groups is demonstrated in Figure 1: 


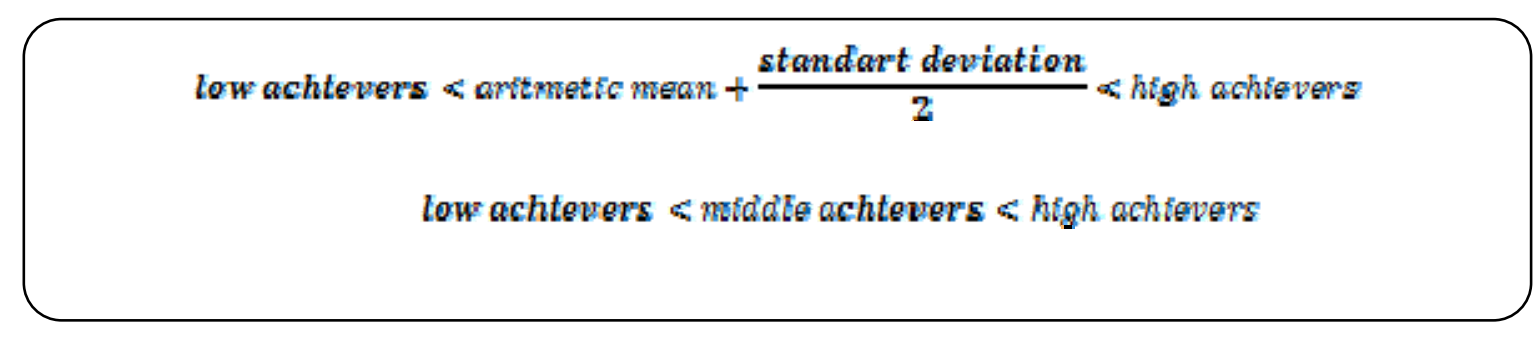

Figure1 Rationale for identifying small discussion groups

As can be seen in Figure 1, if a PST's score was higher than the total of the arithmetic mean and half of the standard deviation, s/he was grouped with the high achievers; if it was lower, $\mathrm{s} /$ he was grouped with the low achievers; and if it was in the middle, $\mathrm{s} /$ he was grouped with the middle achievers. By these criteria, the students with a score between 4 and 10 formed the low achievers group, those with a score between 11 and 16 formed the middle achievers group, and those with a score between 17 and 22 formed the high achievers group.

\section{Data Collection Tools}

The present study made use of three different data collection tools which are described in detail below.

\section{a) Cloning Conceptual Understanding Exam (CCUE)}

The CCUE, originally developed by Lyngved (2009), was redesigned by translating and adapting 10 open-ended and seven multiple-choice questions into the Turkish context. In the Turkish adaptation process of the CCUE, three field experts were consulted for scientific language and content relevancy; then, in light of their feedback, it was finalized. The Cronbach Alpha reliability value of the CCUE was calculated to be 0.78 , which is acceptable for a conceptual understanding test (Fraenkel \& Wallen, 2006). Whole items within the CCUE were evaluated by taking into consideration a pre-designed assessment rubric scaled from 0 to 3 points. The PSTs' scores were ' 0 point' at the lowest and ' 30 points' at the highest, with ' 1 point' for each correct answer and ' 0 point' for the wrong answers in the CCUE.

\section{b) Scientific Scenarios}

Three scientific scenarios were designed by the authors in light of the literature to initiate and engage the PSTs in argumentations. In designing the scenarios, the authors made use of some fictitious events (Appendix 1). These scenarios were critiqued by three experts in linguistics, biology, and argumentation, and in line with the field experts' suggestions, some parts of the scenarios were rewritten. In addition to this, a preliminary scenario was devised to adapt the PSTs to argumentative processes. The scenarios used for argumentations are briefly 
described in Table 1:

Table 1 Scientific Argumentation Scenarios

\begin{tabular}{ll}
\hline \multicolumn{1}{c}{ Title of the Scenario } & \multicolumn{1}{c}{ Content of the Scenario } \\
\hline $\begin{array}{l}\text { Show Your Difference } \\
\text { (Preliminary scenario) }\end{array}$ & emphasis on two different techniques in cloning procedures \\
What is your idea? & $\begin{array}{l}\text { for the differences between natural cloning and artificial cloning as well } \\
\text { as some technical and scientific processes of cloning }\end{array}$ \\
$\begin{array}{l}\text { A Photocopy of a Living } \\
\text { Organism? }\end{array}$ & with scientific controversies regarding a copied living organism \\
Cloning Procedures & with scientific controversies regarding cloning processes \\
\hline
\end{tabular}

\section{c) Semi-structured interviews}

Semi-structured interviews were conducted to reveal the reasons for the emerging relationship between PSTs' argumentation and their knowledge of content. The researchers purposefully selected one PST (25\% is the criterion \& in total three PSTs) from each small discussion group by considering his or her willingness. By this way one student from low achiever, one from middle achiever and one from high achiever group were participated to interview. In order to pose valid and probing interview questions for healthy member checking (Creswell, 2007), the authors conducted a pilot with another three PSTs and some repetitive and incoherent interview questions were taken out of the final protocol and thus the interview protocol was finalized (Appendix 2). The interviews lasted at least 20 minutes for the completion of all main and probing questions.

\section{Procedure}

Argumentation practices lasted seven weeks and the processes are presented in their entirety below in Table 2. At first, the researchers administered the CCUE to the PSTs in an elective course titled 'Special Topics in Biology'. After dividing all PSTs into small discussion groups according to data obtained from the CCUE, there was an explicit introduction of basic argumentation skills and strategies. In order to give some ideas to the PSTs about argumentative discourse in general, the researchers demonstrated some online discussion videos concerning GMOs, cloning, astrology (as a pseudoscience), and the theory of evolution (controversial in nature) in both scientific and socio-scientific contexts. The PSTs were then given some structured documents in the form of worksheets to introduce the Toulmin Argument Model (TAP, 1958) and its basic components as claim, data, warrant, and support. Also, the use of generating counterarguments and rebuttals for the quality of an argumentation was explicitly pointed out. After this explicit introduction to argumentative 
discourse, the PSTs were asked to put forward argumentations in the context of cloning based on the three scenarios 'What's Your Idea?', 'A Photocopy of a Living Organism?', and 'Cloning Procedures'. In the course of the argumentation practices, a researcher first introduced the main idea within each scenario. All members of the small discussion groups read the entire scenarios, and then they argued for or against the embedded controversies to attain general agreement if possible. Also, the authors intentionally remained mostly neutral in the course of these small group discussions.

Table 2 Procedures for Argumentation Practices

\begin{tabular}{|c|c|c|}
\hline $\begin{array}{c}\text { Processing } \\
\text { Time } \\
\text { (Week) } \\
\end{array}$ & Context & Type of Instrument \\
\hline I. & $\begin{array}{l}\text { Administering CCUE and forming small } \\
\text { discussion groups }\end{array}$ & $\begin{array}{c}\text { Cloning Conceptual } \\
\text { Understanding Test (CCUE) }\end{array}$ \\
\hline II. & $\begin{array}{l}\text { Explicit introduction to argumentation and } \\
\text { Toulmin Argument Model (TAP) }\end{array}$ & $\begin{array}{l}\text { Show Your Difference } \\
\text { (Pilot scenario) }\end{array}$ \\
\hline III. -IV. -V. & $\begin{array}{l}\text { Engage participants in argumentation and data } \\
\text { collection }\end{array}$ & $\begin{array}{c}\text { What is your idea? } \\
\text { A Photocopy of a Living } \\
\text { Organism? } \\
\text { Cloning Procedures }\end{array}$ \\
\hline VI. & ntation about genetic & $\begin{array}{l}\text { Worksheets, online discussion } \\
\text { videos }\end{array}$ \\
\hline VII. & Conducting semi-structured interviews & $\begin{array}{l}\text { Semi-structured Interview } \\
\text { Questions }\end{array}$ \\
\hline
\end{tabular}

\section{Data Analysis}

In the literature, much research has been based on the Toulmin Argument Pattern (TAP, 1958) to assess individuals' argumentations (Jimenez-Aleixandre et al., 2000; Erduran et al., 2004). In general terms, the TAP has six components. Three of these (claim, data, and warrant) constitute the grounds for an argument, and the other three components (support, rebuttal, and qualifier) corroborate or complement an argument. The first three components are essential for generating an argument while the other three offer more quality and validity. The structure of the TAP consists of a claim and related data that advocates that claim, warrants (justification) which coordinate the claim (theory) and the data (evidence), supports which increase the power of warrants, qualifiers which specify the validity conditions of an 
argument, and finally rebuttals which identify the conditions that make the claim(s) invalid (Erduran et al., 2004).

To assess the quality of the PSTs' scientific argumentations by means of the TAP, an analytical assessment tool developed by Erduran et al. (2004) was used (Table 3).

Table 3 Argumentation Assessing Tool

\begin{tabular}{lcc}
\hline Level Content & Argumentation Level & Argumentation Score \\
\hline $\begin{array}{l}\text { Level 1argumentation consists of a simple claim versus } \\
\text { a counter-claim or a claim versus a claim. }\end{array}$ & Level 1 & 1 \\
$\begin{array}{l}\text { Level } \mathbf{2} \text { argumentation consists of a claim versus a claim } \\
\text { with data, warrants, or backing but no rebuttals. }\end{array}$ & Level 2 & 2 \\
$\begin{array}{l}\text { Level } \mathbf{3} \text { argumentation consists of a series of claims or } \\
\text { counter-claims with data, warrants, or backings with the } \\
\text { occasional weak rebuttal. }\end{array}$ & Level 3 & 3 \\
$\begin{array}{l}\text { Level } \mathbf{4} \text { argumentation shows a claim with a clearly } \\
\text { identifiable rebuttal. Such an argument may have several } \\
\text { claims and counter-claims. }\end{array}$ & Level 4 & 4 \\
$\begin{array}{l}\text { Level } \mathbf{5} \text { argumentation displays an extended argument } \\
\text { with more than one rebuttal. }\end{array}$ & Level 5 & 5 \\
\hline
\end{tabular}

According to this analytical assessment tool, the quality of an argument is mostly dependent on the presence or absence of justifications and also rebuttals in it. This tool has been used in a number of studies and it has been reported functional for assessing the quality of both scientific and socio-scientific argumentation (Osborne, Erduran, \& Simon, 2004). The quality of the PSTs' arguments was assessed by taking into consideration argumentations generated in the context of one of the scenarios (What is your idea?). The researchers selected this scenario for the reason that in the process of arguing it took longer compared to the other scenarios. The authors could therefore detect the quality of the PSTs' argumentation quite clearly through ample data. Moreover, the PSTs were thought to be more experienced in argumentation since they engaged in this scenario at the close to end of implementation.

There were three steps of data analysis in the present study and they are explained in detail in the following sections. Firstly, to reveal the quality of the PSTs' argumentation, their audio-recorded argumentations were transcribed verbatim. Before all the stored data were encoded, we decided to design a codebook in order to deal with large chunks of data. Then, two authors independently encoded what counts as claim(s), data, warrant(s), support(s), qualifier(s), and rebuttal(s) according to the pre-determined codebook. After completion of the encoding process, the two researchers came together to compare and discuss differences 
for the validity and reliability criteria in terms of peer review or debriefing (Lincoln \& Guba, 1985). In this process, inter-coding reliability was more than $85 \%$. In the second step, quantitative data analysis was conducted. To do this, the levels of the PSTs' argumentations, which were qualitatively analyzed in the first step of data analysis, were re-encoded as continuous variables (e.g. level 1 argumentation: 1 point; level 2 argumentation: 2 points; for more detailed description, see Table 2) in order to carry out a quantitative data analysis. To decide whether the quantitative-oriented data were distributed normally, the Shaprio-Wilk test was conducted. Then, the Kruskal Wallis- $\mathrm{H}$ test was used to reveal whether there is a significant relation between the PSTs' argumentations and their prior knowledge of content. In the final step, the semi-structured interviews were analyzed. As with the first step, all conversations of the three PSTs during the interviews were transcribed verbatim. Then the authors designed an initial codebook to tackle the raw data. Afterwards, the two authors individually encoded the verbatim transcripts in light of the pre-designed codebook and noted whenever there was an emerging code reflecting the PST's articulation more closely. To increase the reliability of the coding process, the two authors first compared their independently encoded data, and then discussed the differences. After deciding on the final codes, categories, and themes in a coherent way, the authors specified significant reflections and statements of the three PSTs and thus inter-coder reliability was more than $80 \%$ for the interview analysis.

\section{Findings}

In this part, the findings obtained from both the qualitative and quantitative data analyses are presented in detail.

\section{Investigating Argumentation Quality among Small Discussion Groups}

The quality of the scientific argumentations generated by the PSTs was examined for each small discussion group. In the process of argumentation, the PSTs tried to suggest solutions for cloning issues in a given scientific context by generating arguments and counter arguments. To show the quality of the PSTs' argumentations, some quotations are given below:

\section{Example of level 1 argumentation}

$\mathbf{S}_{1}:$...if we did it to a person, it wouldn't influence the sleeping metabolism, would it?

$\mathbf{S}_{\mathbf{2}}$ : DNA is a different thing (concept), I think.

Claim (S1) + Claim (S2) 


\section{Example of level 2 argumentation}

S1: I mean, there is a difference, and you agree with my main argument?

S2: I said there is a difference and its justification is mutation. In a long process the mutation can occur with respect to identical twins only if there is a mutational situation. But in this scenario, it is implied that identical twins are associated with mitotic division. It is the same with the mother. In the process of cloning, due to the external effects, the offspring may not be identical to the mother.

\section{Claim (S1) + [Claim + Warrant + Backing + Data $\left.\left(\mathbf{S}_{2}\right)\right]$}

\section{Example of level 3 argumentation}

S1: In terms of identical twins, they are always the same age, but, in the process of cloning, copied living beings are the same age as their mothers.

S2: It is not true for the age, but bodily it is true.

S1: In conclusion, a copied living being surpasses him or her in all experiences?

S1: Until the cloning moment, a human being has many experiences.

\section{[Claim + Warrant $\left.\left(\mathbf{S}_{1}\right)\right]+$ Rebuttal (weak) $\left(\mathbf{S}_{2}\right)+\left[\right.$ Data + Warrant $\left.\left(\mathbf{S}_{1}\right)\right]$}

\section{Example of level 4 argumentation}

S1: In my opinion, there are no data to support that argument because the egg and sperm cells combine to form a zygote. In this phase, there are meiosis and mitosis divisions. Moreover, there is crossing over mechanism in the process of meiosis. Due to the crossing over mechanism, there is a part-exchange process; therefore, there may be different individuals.

S2: But in the process of cloning, you will have a very same individual, for instance, if she is Aysun, you are going to form a very same Aysun. This situation is the same as being a Japanese or Chinese person; but there is crossing over mechanism in this process, I mean genetically different individuals will be formed.

S3:... For instance, having the same height, the same color?

$$
\begin{aligned}
& {\left[\text { Claim + Warrant + Claim + Backing + Warrant }\left(\mathbf{S}_{1}\right)\right]+\left[\text { Rebuttal }^{1}\right. \text { (strong) + }} \\
& \text { Backing + Data + Rebuttal + Data } \left.\left(\mathbf{S}_{2}\right)\right]+ \text { Data }\left(\mathbf{S}_{3}\right)
\end{aligned}
$$

\section{Example of level 5 argumentation}

S1: To our knowledge in terms of one celled twin... I mean, one cell is divided through mitosis and two new cells are formed, but in the process of cloning you do not form a new, very similar cell, you do form a living being by injecting some forms of cells to others.

S2: ... it is formed...

S2: The copied living being is born in a regular way, but it is older than a newborn.

S1: I think that all features of an organism can pass through the cloning process, but it is not the same as identical twins. I mean, a copied organism can be the same as the mother in terms of appearance or genetic structure, but a copied organism is different from identical twins, because if we consider a process in which one is copied or the process of being identical twins, in terms of 
the former, you split the fertilized egg cell in two parts but with respect to the latter, normally and naturally a fertilized egg cell is divided into two and more very same cells.

\section{Claim $\left(\mathbf{S}_{1}\right)+$ Backing $\left(\mathbf{S}_{2}\right)+\left[\right.$ Backing + Rebuttal $\left.\left(\mathbf{S}_{2}\right)\right]+[$ Backing + Rebuttal + Backing + Rebuttal + Data $\left.\left(\mathbf{S}_{1}\right)\right]$}

Following the analysis above, the argumentation frequencies of high, middle, and low achievers were analyzed to determine whether or not argumentation quality changes within small discussion groups, as seen in Figure 2:

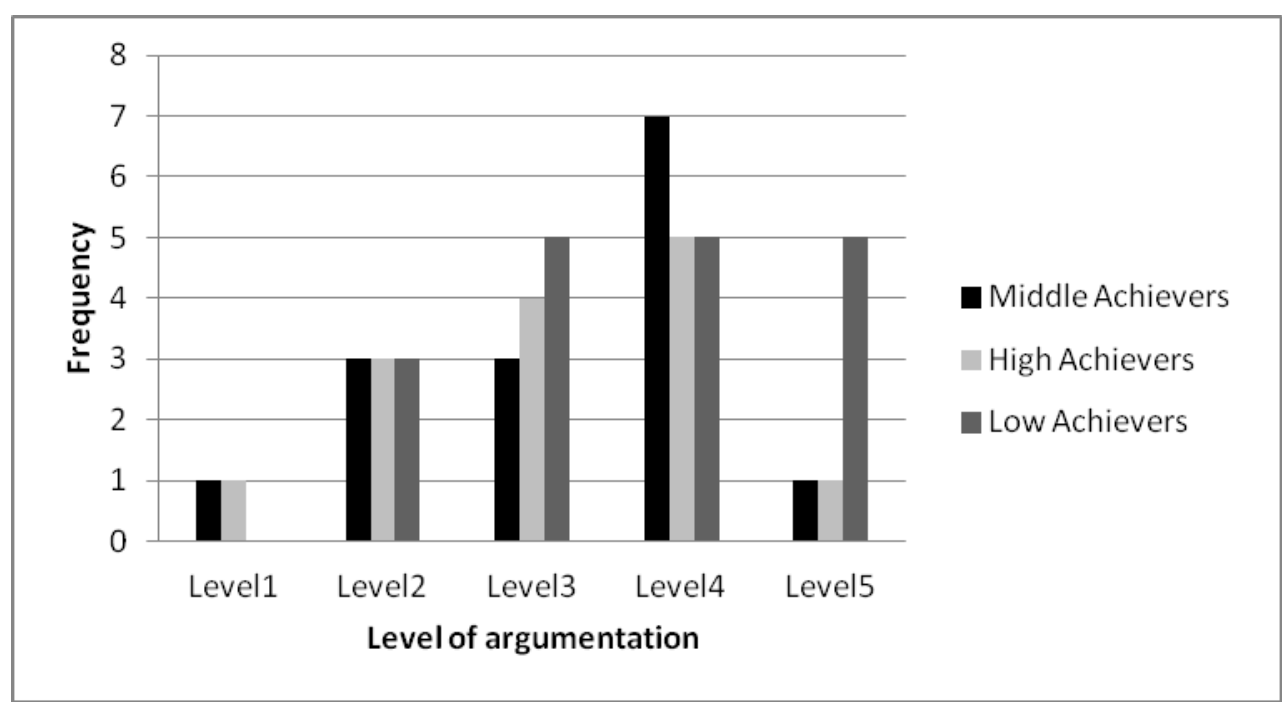

Figure 2 Frequencies of Whole Groups Argumentation Quality Levels

Figure 2 (axis $y$ shows the number of generated argumentation episodes while axis $x$ shows divergent levels of argumentations from the simplest to the most sophisticated one), shows the frequencies of high, middle, and low achievers' scientific argumentations. First of all, more than two thirds of level 5 argumentations weregenerated by low achievers (approximately 72\%). Secondly, in terms of articulating level 4 argumentations, almost half of them were generated by middle achievers $(42 \%)$, with the high and low achievers having the same frequencies (29\%). Moreover, more than a third of level 3 argumentations were generatedbylow achievers (42\%). For level 2 argumentations, it can be asserted that they were generatedequallyin total by all small discussion groups, in other words, regardless of being more or less knowledgeable about cloning, all groups could coordinate (warrant) a theory (claim) with relevant evidence (data). Only middle and high achievers articulated level 1 argumentation, however, their frequency level in total argumentations is moderately lower (less than $5 \%$ of total argumentations) and that situation supports the idea that PSTs generally tended to justify their claims and it might be possible by means of explicit introduction of an 
argumentation. When the overall results are considered, it can be seen that the low achiever PSTs generated more sophisticated argumentations compared to the other two groups but in order to prove that claim we needed further (quantitative) analyses presented in detail below.

\section{Comparing Argumentation Quality Differences}

In this section the data is exhibited about whether knowledge of content has a significant effect on the PSTs' argumentation quality. In order to examine the research question of the current study, first the Shapiro-Wilk normality test and then the Kruskal Wallis test results are presented.

Table 4 Shapiro-Wilk Normality Test

\begin{tabular}{lccccc}
\hline & $\mathbf{N}^{*}$ & $\boldsymbol{X}$ & $\mathbf{S . S .}$ & $\mathbf{Z}$ & $\mathbf{p}$ \\
\hline Scores & 47 & 3,38 & 1,09 &, 904 &, 001 \\
\hline$p<05$ and $N^{*}$ shows the total frequency of argumentation episodes & generated by participants
\end{tabular}

According to Table 4, the quantified argumentation scores do not demonstrate a normal distribution $(\mathrm{p}<.05)$, therefore the Kruskal Wallis-H (as a non-parametric test) was used to detect any relation between the PSTs' argumentation quality and their domain specific knowledge of cloning in the scientific context.

Table 5 Kruskal Wallis-H Test Results

\begin{tabular}{lccccc}
\hline Groups & $\mathbf{N}^{*}$ & $\begin{array}{c}\text { Degree of } \\
\text { freedom(df) }\end{array}$ & Mean rank & $\mathbf{X}^{\mathbf{2}}$ & $\mathbf{p}$ \\
\hline Low achievers & 18 & 2 & 27,14 & 1,769 &, 413 \\
Middle achievers & 15 & & 22,87 & & \\
High achievers & 14 & & 21,18 & & \\
\hline
\end{tabular}

$p>.05$ and $N^{*}$ shows the frequency of argumentation episodes generated by participants

The results of the Kruskall Wallis-H test, as can be seen in Table 5, show that the quality of argumentations generated by the PSTs is not significantly affected by their content knowledge of cloning $\left[\mathrm{X}^{2}(2)=1.769, \mathrm{p}>0.05\right]$. This finding also confirms that, in the scope the present study, an individual's domain specific content knowledge is not a determining factor in articulating higher or lower quality argumentations.

\section{PSTs views on argumentation processes}

In this section, excerpts from the interviews with the three PSTs are presented in the context of their views on their argumentations. 


\section{Argumentation as persuasive discourse}

Below, middle, and low achiever's significant statements as regards the first interview question (When you had an alternative position(s) or idea(s) in the process of argumentations, how did you convince counter positioned group member(s), or did you end up convinced by them?)

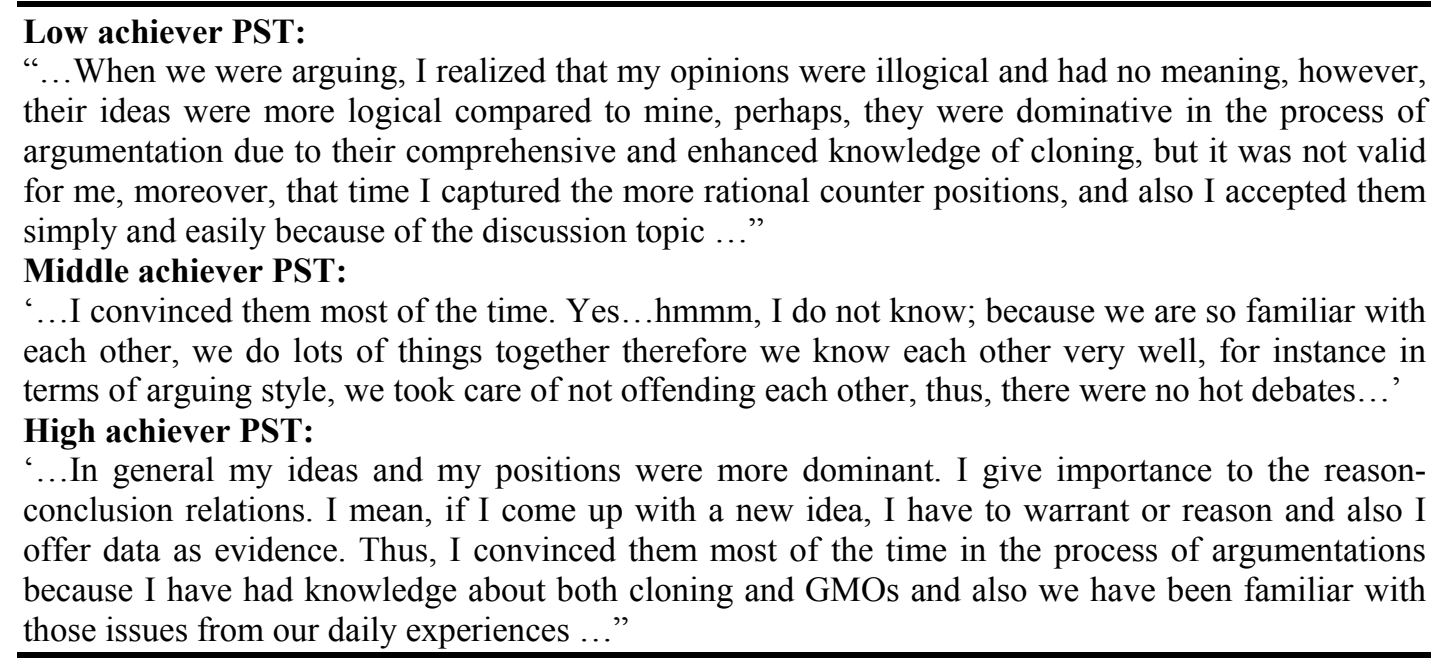

In terms of first question, in general, all PSTs stated that in the process of argumentations their own ideas or positions were outweighed. According to high and low achiever PSTs, being familiar with content is decisive in constructing higher quality argumentations. However, the middle achiever PST did not mention content knowledge rather she remarked that in the process of argumentation, her small discussion group members did not reflect their opinions relevant to the nature of argumentative discourse and they could not test the validity of presenting arguments, because their articulations were not competing, conflicting, or challenging. Presumably, it can be asserted that lack of knowledge of PSTs might restrict them in assessing alternative points of views as in the form of counter arguments and make attacks on grounds of counter arguments. To advocate, as all PSTs indicated, in the course of arguing, their initial arguments were immediately dominant with no need to generate counter arguments in divergent aspects. Therefore, it may be thought that insufficient content knowledge might lead PSTs to admit that knowledge of content was crucial in the course of debating and assessing alternatives of a controversial issue and when they consumed all their existing knowledge of content, they were obliged to accept more dominant arguments instead of outweighing alternatives. 


\section{Competence in argumentative skills and strategies}

The second question was about whether the PSTs considered themselves to be efficient arguers when arguing cloning in an unscientific context and some significant excerpts are presented below.

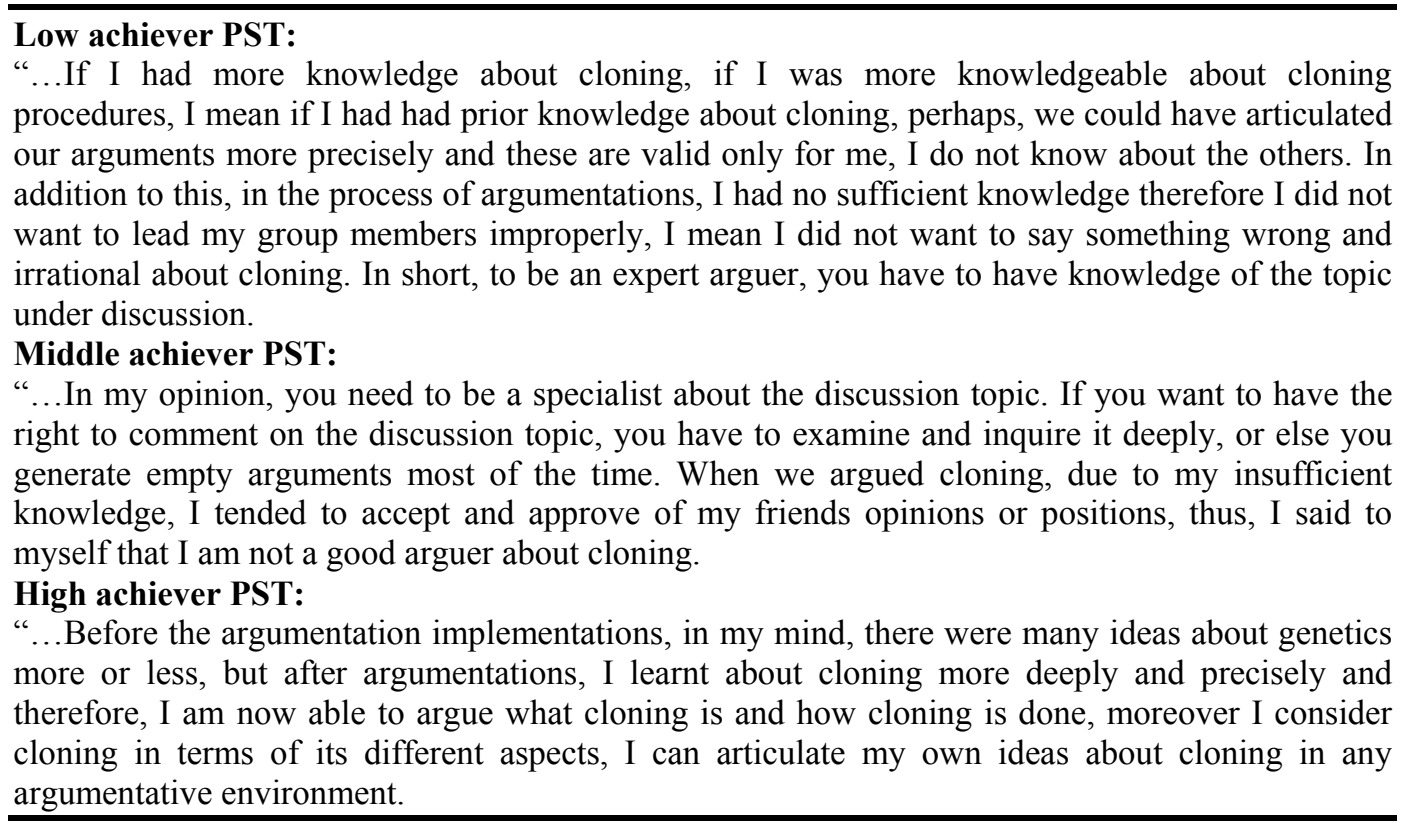

For this item, all PSTs emphasized the role of being knowledgeable for extensive argumentation. Low and middle achiever PSTs clearly pointed out that in order to be a versatile arguer regardless of the scope of the argumentation topic, an individual should have and also apply his or her exhaustive knowledge. Moreover, the high achiever PST focused on general knowledge of the subject. In addition to this, the high achiever PST mentioned that in the process of argumentation, she was obliged to operate her prior knowledge of genetics instead of applying a related terminology about cloning. At this point, it can be suggested that, especially for the low and middle achievers, they had some difficulties in transferring and applying their moderate knowledge of content in the course of argumentations. Thus, they tended to interrogate why they could not use their moderate knowledge in argumentations. Possibly, it might be due to inadequate acquisition of argumentation skills and when the PSTs discussed major topics, they attained to assess alternative viewpoints initially, however, when they attempted to extend and elaborate the scope of their argumentations, they had to use, generally speaking, off-topics such as applying general knowledge base about genetics instead of cloning-related sub-concepts and explanations. 


\title{
Effect of content knowledge
}

The third question was asked for revealing whether the PSTs might generate higher quality arguments if another topic (instead of cloning) was handled in the process of argumentations and some relevant quotations are presented below.

\begin{abstract}
Low achiever PST:
"...If we debated a topic that I knew better, I would argue it better than cloning. I wish to argue a topic that I like to consider and discuss it more. For instance, if we argued acid rains and their detrimental effects on nature and environment, to what extent acid rains cause environmental pollution...I come from Rize (a city located in Eastern Black Sea Region), I suppose that in that region there were a lot of acid rains in the years before. Therefore I am interested in arguing and considering acid rains and there is a clear link between environmental pollution and acid rains.

Middle achiever PST:

"...because, GMO is more popular, there are more information resources about GMO and that is not valid for cloning, because we always watch the different news with respect to GMOs on TV, we meet GMOs on popular scientific magazines, newspapers, therefore, GMOs sound familiar. Perhaps, I would argue scientific topics more extensively compared to socio-scientific issues.

\section{High achiever PST:}

“...I can argue a topic better if I have sufficient knowledge and an idea about it. I mean if I am more knowledgeable about discussion topic, I can do my best. I suppose that I am sufficient in arguing GMOs as a socio-scientific issue, I mean, this confidence stems from my curiosity, interest and search about an issue. If you have adequate knowledge about any topic, you can argue it wisely in any situation and with anyone.
\end{abstract}

With respect to the third question, the three PSTs commonly expressed that the effect of popularity of a topic and their interest serve as a function in engaging argumentation. However, high and low achiever PSTs laid stress on having content knowledge in addition to individual interest and curiosity in argumentation. According to the low achiever PST, as different from the other two, everyday (familiar) issues may be debated comprehensively compared to less known issues and as a unique statement the middle achiever PST commented that she is able to argue scientific context better than socio-scientific context. By considering some common points of view of the PSTs, two interpretations can be put forward. Firstly, being familiar with the content of the argumentative tasks can positively contribute to debaters' argumentations' structure and nature (von Aufschnaiter, Erduran, Osborne \& Simon, 2008). Secondly, SSIs cannot be limited by narrower scopes as they have inherently ill-structured and open-ended aspects (Sadler \& Donnelly, 2006; Sadler \& Zeidler, 2005a), conversely, scientific contexts, most of the time, can be explained and discussed by assessing a single discipline. Therefore, she, as a middle achiever, thinks of SSIs as more multifaceted and challenging, less debatable by evaluating more alternatives compared to scientific and concrete aspects of cloning. 


\section{Interrupted argumentative discourse}

The fourth question aimed to capture whether argumentative processes come to a halt for reasons such as lack of knowledge of content or a sudden consensus.

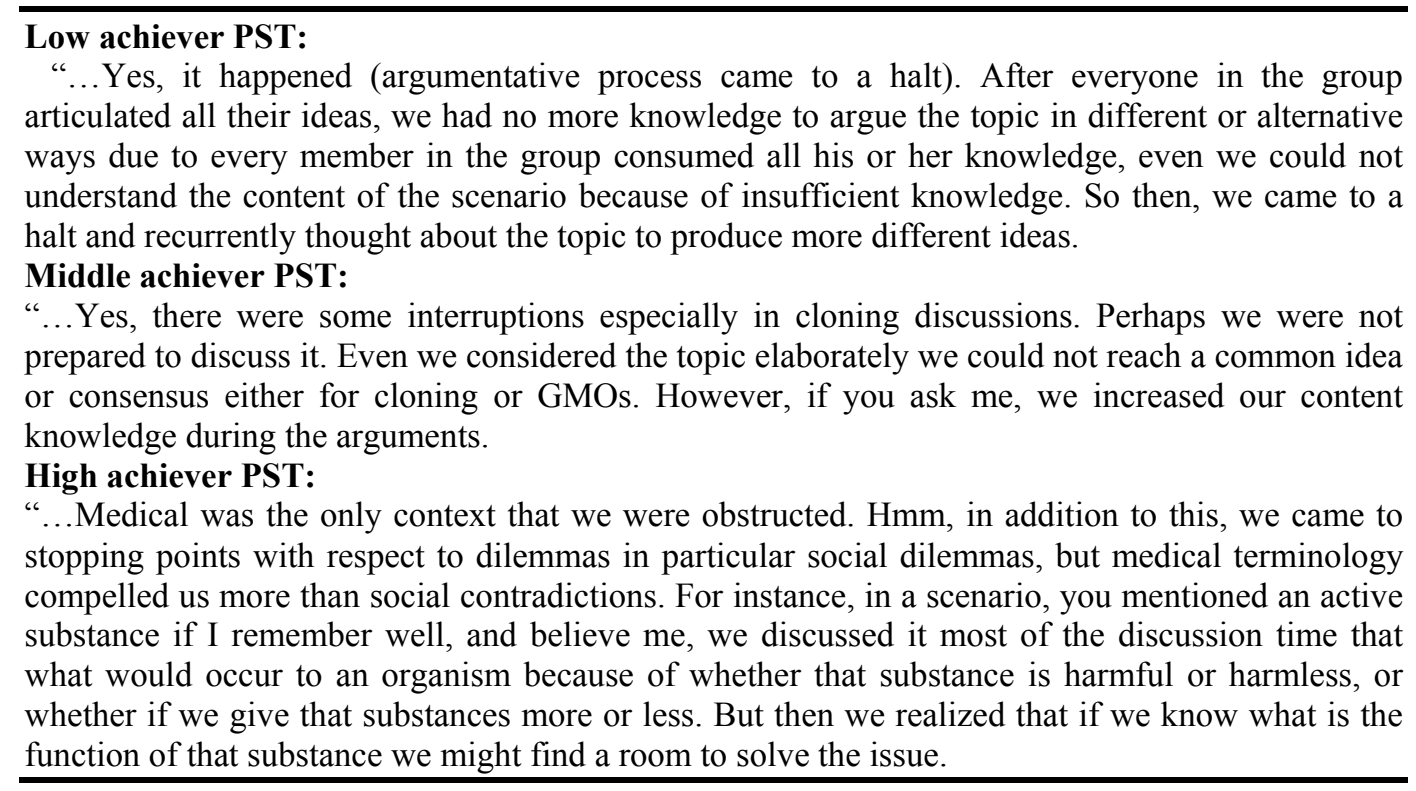

In general, all PSTs commented that in the process of argumentation they came to a stopping point (dead-end) for different reasons. The low achiever PST indicated that the stopping point occurred because of lack of knowledge of content, but neither the high nor the middle achiever PSTs mentioned insufficiency of content knowledge as a reason that causes to stop (restrict) the discussion. Moreover, the middle achiever PST expressed that they could not maintain their hot debates because of unwillingness and due to not coming through anyway. As a conclusive comment, there are two salient points. At first, again, because of inadequate content knowledge of details of cloning and its sub-concepts, especially, small discussion groups that consisted of low achievers might not maintain discussions. On the other hand, the two other groups (high and middle achievers) did not mostly express the negative effects of being less knowledgeable about cloning. However, as is obvious in the middle achiever's articulation, there were some motivational determinants in engaging and sustaining argumentative discourse. As Schunk and Pintrich (1996) state, content of the given tasks should be achievable and attainable, in other words, individuals should be given neither too challenging nor very simple tasks, rather, perhaps, the tasks that are moderate are mostly appropriate for engaging in and sustaining them. Thus, because of the difficulty of argumentative tasks, small discussion groups did not reach any conclusions and it could discourage them to engage in more argumentative discourse moments. As expected, they preferred to give them up before arguing at length. 


\section{Discussion and Conclusions}

In the present study, it is aimed to reveal whether there is a significant relation between content knowledge of cloning and scientific argumentation quality and to find out presumptive reasons for that relation. The findings from quantitative analyses show that the PSTs generally tend to justify their claims with data and/or warrant. Moreover the results of the Kruskal Wallis- $\mathrm{H}$ test show that PST content knowledge about cloning is not a determining factor in the quality of their arguments. The qualitative results of the study indicate that when the PSTs were asked about convincing strategies in argumentation high and low achievers mentioned the importance of content knowledge, but the middle achievers did not. According to her, familiarity with group members was influential in convincing. Also it is clear from the results of second interview question that the PSTs thought that being more knowledgeable makes them better arguers. Furthermore, the participants explained that the popularity of a topic determines the quality of arguments that they generated. Lastly the PSTs specified two main reasons - content knowledge and motivational factors that cause argumentation to come stopping point.

Our finding that the PSTs tended to justify their claims corroborates Kuhn's (1991) idea that argumentation skills are naturally present in students. The low quality arguments that they generated (Level 1 and Level 2) may be due to short intervention periods. Actually Osborne et al. (2004) did not detect significant improvement in students' quality of arguments after a relatively short intervention. Moreover the finding of the present study that content knowledge about cloning is not a determining factor in the quality of the PSTs' arguments does not match with the conclusions of von Aufscnaiter et al. (2008) and Cross, Taasoobshirazi, Hendricks and Hickey (2008). Also, Maloney and Simon (2006), Roychoudhury and Rice (2009), Clark and Sampson (2008), Sampson and Clark (2011), Tavares et al. (2010) and Acar (2008) similarly suggested that knowledge of content is a critical determinant in contributing quality of scientific argumentations of students. Mainly those studies have emphasized that an individual's substantial body of knowledge may affect the quality of his/her argumentations in scientific contexts. In-depth critiques of those studies also demonstrate that interconnectedness between quality of scientific argumentations and scientific knowledge is not unidirectional. Put differently, a considerable increase in scientific knowledge is explicitly attributed to the quality of scientific argumentations whereas in the course of argumentation students may develop and improve their knowledge of science. On the other hand, as Hakyolu and Ogan-Bekiroglu (2011) and Eskin and Bekiroglu (2009) hold, scientific knowledge is not a primary component making a scientific argument better. But, at 
this point, it has to be questioned why there is a salient discrepancy between the results of this study and other. It could be due to the sample size. In our study there were only 12 PSTs which is a very small sample size compared to most of the studies in the literature. Conducting this study with such a small sample size may have negatively affected the separation of high, low, and middle achievers with precision. Moreover the instrument used to determine the participants' content knowledge may have influenced the results. As was mentioned before, this test involves questions related to cloning and the participants were thought to have some basic knowledge of genetics. The highest score that the participants got from this questionnaire was 22 out of 30. Therefore the PSTs we categorized as high achievers might have less content knowledge than anticipated. Lastly we formed three groups with respect to content knowledge, specifically we had middle achievers. Sampson and Clark (2011) utilized two groups as high and low achievers and found a significant relationship between content knowledge and quality of argumentation. So when the number of formed groups increases, this might reduce the difference between groups with respect to content knowledge.

The findings from interviews do not confirm the findings from statistical analyses. For instance, low and high achievers obviously indicated that their insufficient science knowledge limited group members in generating more complex scientific arguments. Moreover, middle achievers mentioned that their small discussion group was not bound up with the nature of argumentation. The high achiever stated the importance of causality in articulating arguments in a scientific context. However, they could not produce strong rebuttals and warrants compared to the other two groups. For instance, a high achiever clearly stated the importance of connectedness of cause and effect by saying '... In the process of arguing, generally speaking, my ideas were predominated, because, I highly pay attention to cause-effect connection.' As seen in the excerpts of the PSTs, even though the three interviewees commonly indicated that science knowledge has a priority in articulating higher quality scientific argumentations, within the scope of the present study, there is not statistically significant difference among their argumentations.

This inconsistency can be dealt with by paying attention to reciprocal interactions among argumentation skills and strategies, social environment, and cultural norms. As Ford (2008) proposed, when an individual's existing and integrated cognitive network is not interrogated based on a specific culture in which the individual lives, s/he immediately and easily admits the knowledge claims that are presented moderately and strongly refers to the 
vital importance of argumentation skills and strategies. Moreover, in order to articulate better scientific argumentations and to convince counter positioned individuals, as Grasso, Cawsey, and Jones (2000) pointed out, in addition to individual argumentative skills and strategies, the rationality and validity criteria have to be met. For example, a low achiever PST expressed that '...His explanations seemed to me more valid and rational, and when I re-evaluated my arguments, I saw that those were all incoherent and made no sense.' In addition to lack of basic argumentation skills and strategies, insufficient rationality of PSTs scientific argumentations might generate lower quality argumentations, in other words, they did not meet the rationality criterion of the articulated argumentations. Furthermore, unexpectedly, the low achievers were able to generate higher quality argumentation compared to the two other groups. Even though low achievers had no substantial scientific knowledge of cloning, by means of their high attention concentrating on the presented scenario and its different aspects and behaved as taking seriously argumentation implementations by putting much effort in dealing with scientific cloning issues. For instance, a low achiever pointed that '... I do not know why my discussion group could not produce higher-quality arguments. Perhaps it was due to not being disposed to engage in it. I mean our effort was frustrating, because although we had debated both detrimental effects of GMOs and cloning, nobody listens to and considers our decisions and they [politicians and scientists] have been proceeding with their decisions to produce GMOs and cloned organisms anyway.' As a final comment, as Kim and Song (2005) report, in the course of engaging in scientific argumentations, individuals tend to benefit from both social and cognitive strategies and intentional focusing on discussion processes should be considered as critical constituents. Also, within the scope of the study, PSTs supported that they may engage in more extended scientific argumentations if the topic under discussion is more attractive. To support, some studies reveal that in engaging both scientific and socio-scientific argumentations, in addition to knowledge of content of an individual, his or her attitudes and beliefs about the topic under discussion may be effective in articulating argumentations of different qualities (Erduran et al., 2004; Zeyer \& Roth, 2009). Beyond, as the present study implicitly confirms, PSTs' scientific argumentation quality may be manipulated in favour of some structures as general argumentation skills and strategies, concentrating on engagement in argumentation, social connections and interactions, the environment, and finally bound up with the general lines of argumentation. Further studies can investigate the relationship between content knowledge and argumentation quality with different subject matters and larger sample sizes to provide more evidence for the contradictory results presented in the literature. 


\section{References}

American Association for the Advancement of Science. (2000). Designs for science literacy. Washington.

Acar, O. (2008). Argumentation skills and conceptual knowledge of undergraduate students in a physics by inquiry class. Unpublished doctoral dissertation, The Ohio State University, College of Education and Human Ecology, USA.

Bricker, L. A., \& Bell, P. (2008). Conceptualizations of argumentation from science studies and the learning sciences and their implications for the practices of science education. Science Education, 92, 473-498.

Clark, D. B., \& Sampson, V. (2008). Assessing Dialogic Argumentation in Online Environments to Relate Structure, Grounds, and Conceptual Quality. Journal of Research in Science Teaching, 45, 293-321.

Creswell, J. W. (2007). Qualitative inquiry and research design. Thousand Oaks, London: Sage Publications.

Cross, D., Taasoobshirazi, G., Hendricks, S., \& Hickey, D. T. (2008). Argumentation: A strategy for improving achievement and revealing scientific identities. International Journal of Science Education, 30(6), 837-861.

Council of Ministers of Education, Canada. (1997). Common framework of science learning outcomes K to 12: Pan-Canadian protocol for collaboration on school curriculum for use by curriculum developers. Toronto, Canada.

Curriculum Council of Western Australia. (1998). The curriculum framework for kindergarten to Year 12 education in Western Australia. Perth, Western Australia.

Dawson, V., \& Schibeci, R. (2003). Western Australian high school students' attitudes towards biotechnology processes. Journal of Biological Education, 38(1), 1-6.

Driver, R., Newton, P., \& Osborne J. (2000). Establishing the Norms of Scientific Argumentation in Classrooms. Science Education, 84, 287-312.

Duschl, R. A., \& Osborne, J. (2002). Supporting and promoting argumentation discourse in science education. Studies in Science Education, 38, 39-72.

Erduran, S. (2007). Breaking the law: promoting domain-specificity in chemical education in the context of arguing about the periodic law. Found Chemistry, 9, 247-263.

Erduran, S., \& Jiménez-Aleixandre, M. P. (2007). Argumentation in science education: Perspectives from classroom-based research. London: Springer. 
Erduran, S., Simon, S., \& Osborne, J. (2004). TAPping into argumentation: Developments in the application of Toulmin's argument pattern for studying science discourse. Science Education, 88, 915-933.

Eskin, H., \& Bekiroglu, F. O. (2009). Investigation of A Pattern Between Students' Engagement in Argumentation and Their Science Content Knowledge: A Case Study. Eurasia Journal of Mathematics, Science and Technology Education, 5(1), 63-70.

Ford, M. (2008). Disciplinary authority and accountability in scientific practice and learning. Science Education, 92(3), 404-423.

Fraenkel, J. R., \& Wallen, N. E. (2006). How to design and evaluate research in education. (6. Edition). New York: McGraw-Hill International Edition.

Grasso, F., Cawsey, A., \& Jones, R. (2000). Dialectical argumentation to solve conflicts in advice giving: a case study in the promotion of healthy nutrition. International Journal of Human-Computer Studies, 53, 1077-1115.

Hakyolu, H., \& Ogan-Bekiroglu, F. (2011). Assessment of Students' Science Knowledge Levels and Their Involvement with Argumentation. International Journal for CrossDisciplinary Subjects in Education, 2(1), 264-270.

Jimenez-Aleixandre, M. P., Rodriguez, A. B., \& Duschl, R. A. (2000). "Doing the Lesson” or "Doing Science": Argument in High School Genetics. International Journal of Science Education, 84, 757-792.

Kim, H., \& Song, J. (2005). The Features of Peer Argumentation in Middle School Students' Scientific Inquiry. Research in Science Education, 36(3), 211-233.

Kolstø, S. D. (2001). Scientific literacy for citizenship: Tools for dealing with the science dimension of controversial socioscientific issues. Science Education, 85, 291-310.

Kuhn, D. (1993). Science as argument: Implications for teaching and learning scientific thinking. Science Education, 77(3), 313-337.

Kuhn, D. (1991). The Skills of Argument. Cambridge, England: Cambridge University Press.

Lincoln, Y. S., \& Guba, E. G. (1985). Naturalistic Inquiry. Beverly Hills, CA: Sage.

Lyngved, R. (2009). Learning about cloning: developing student knowledge and interest through an interactive, context-based approach. Nordina, 5(2), 142-157.

Maloney, J., \& Simon, S. (2006). Mapping children's discussion of evidence in science to assess collaboration and argumentation. Science Education, 28(15), 1817-1841.

Means, M.L., \& Voss, J.F. (1996). Who reasons well? Two studies of informal reasoning among children of different grade, ability, and knowledge levels. Cognition and Instruction, 14, 139-178. 
Roychoudhury, A. \& Rice, D. (2009). Discourse of Making Sense of Data: Implications for Elementary Teachers' Science Education. Journal of Science Teacher Education, 21, 181-203.

Osborne, J., Erduran S., \& Simon, S. (2004). Enhancing the Quality of Argumentation in School Science. Journal of Research in Science Teaching, 41(10), 994-1020.

Patton, M. Q. (1990). Qualitative evaluation and research methods (2nd ed.). Newbury Park, CA: Sage.

Perkins, D. N., Farady, M., \& Bushey, B. (1991). Everyday reasoning and the roots of intelligence. In J. F. Voss, D. N. Perkins, \& J. W. Segal (Eds.), Informal reasoning and education (pp. 83-105). Hillsdale, NJ: Lawrence Erlbaum Associates.

Pintrich, P. R., \& Schunk, D. H. (2002). Motivation in Education, Teacher and Classroom Influences. Pearson Education, Inc., Upper Saddle River, New Jersey, 07458.

Sadler, T. D., \& Donnely, L. A. (2006). Socioscientific Argumentation: The effects of content knowledge and morality. International Journal of Science Education. 28(12), 1463-1488.

Sadler, T. D., \& Fowler, S. R. (2006). A Threshold Model of Content Knowledge Transfer for Socioscientific Argumentation. Science Education, 90, 986-1004.

Sadler, T. D., \& Zeidler, D. L. (2005a). The significance of content knowledge for informal reasoning regarding socioscientific issues: Applying genetic knowledge to genetic engineering issues. Science Education, 89, 71-93.

Sadler, T. D. (2004). Informal reasoning regarding socioscientific issues: A critical review of research. Journal of Research in Science Teaching, 41(5), 513-536.

Sampson, V., \& Clark, D. (2011). A Comparison of the Collaborative Scientific Argumentation Practices of Two High and Two Low Performing Groups. Research in Science Education, 41, 63-97.

Simon, S., \& Johnson, S. (2008). Professional learning portfolios for argumentation in school science. International Journal of Science Education, 30, 669-688.

Simon, S., Erduran, S., \& Osborne, J. (2006). Learning to Teach Argumentation: Research and development in the science classroom. International Journal of Science Education, $28,235-260$.

Tavares, M. L., Jimenez-Aleixandre, M. P., \& Mortimer, F. E. (2010). Articulation of Conceptual Knowledge and Argumentation Practices by High School Students in Evolution Problems. Science and Education, 19, 573-598. 
Topçu, M. S., Sadler, T. D., \& Tüzün-Yılmaz, Ö. (2010). Preservice Science Teachers' Informal Reasoning about Socioscientific Issues: The influence of issue context. International Journal of Science Education, 32(18), 2475-2495.

Toulmin, S. (1958). The Uses of Argument. New York: Cambridge University Press.

Venville, G., \& Dawson, V. M. (2010). The Impact of a Classroom Intervention on Grade 10 Students' Argumentation Skills, Informal Reasoning, and Conceptual Understanding of Science. Research in science education, 47(8), 952-977.

von Aufschnaiter, C., Erduran, S., Osborne, J., \& Simon, S. (2008). Arguing to learn and learning to argue: Case studies of how students' argumentation relates to their scientific knowledge. Journal of Research in Science Teaching, 45(1), 101-131.

Yoon, S. (2008). Using Memes and Memetic Processes to Explain Social and Conceptual Influences on Student Understanding about Complex Socio-Scientific Issues. Journal of Research in Science Teaching, 45(8), 900-921.

Zeyer, A., \& Roth, W. M. (2009). A mirror of society: a discourse analytic study of 15- to 16year-old Swiss students' talk about environment and environmental protection. Cultural Study of Science Education, 4, 961-998.

Zohar, A. (2007). Science teacher education and professional development in argumentation. In Erduran, S. and Jiménez-Aleixandre, M. P. (2007). Argumentation in science education: Perspectives from classroom-based research (245-268). London: Springer. 


\section{Appendix-1}

\section{Cloning Procedure}

In the process of cloning, a mature sheep's udder cells are isolated and they are kept in culture until they reach the phase called G0 or stopping (stable) phase and their cell divisions and growing processes are stopped. An udder cell under aforementioned conditions is selected and it is combined with another cell which is obtained from other sheep and its nucleus is isolated before the combination process. Hereby, genomes of former mature (cell nucleus which carries whole genetically material of the organism) sheep and egg cells genome are changed. In the following process, egg cell is developed in lab conditions, if the development of the egg is normal, it is transferred to sheep's womb belongs to surrogate. During history of the cloning trials, 277 embryos were formed by operating above mentioned technical cloning procedures. Only 29 of 277 were able to develop as sufficient for transferring into surrogates. Interestingly, one of the 29 combinations was successful to live and its name is Dolly!

\begin{tabular}{|c|c|}
\hline Claim Box I & Claim Box II \\
\hline $\begin{array}{l}\text { - Dolly was not created by cloning a } \\
\text { sheep. } \\
\text { - Dolly is the name of a living organism } \\
\text { which is created through a cell that is } \\
\text { obtained from a mature sheep's udder } \\
\text { cell. } \\
\text { In the process of cloning genetic } \\
\text { material remains unchanged. }\end{array}$ & $\begin{array}{l}\text { - Even though genetic engineer will be able to copy a } \\
\text { human, it will not be the same completely with original } \\
\text { human. } \\
\text { Individuals are not specified with only their genetic } \\
\text { structure and every cells of a mature human has different } \\
\text { genetic features and structures. } \\
\text { Copied organism will not be the same completely with the } \\
\text { original organism due to possible different life and } \\
\text { everyday experiences. Even in the full sense of the word } \\
\text { one celled twins are copied organisms but they may have } \\
\text { different characteristic features, for instance their brain } \\
\text { development can differ from each other due to personal } \\
\text { life experiences. }\end{array}$ \\
\hline
\end{tabular}

\section{Aylin and Merve formed the Claims Box I and Claim Box II in the light of above mentioned text and you are required to assess their claims in the line with below mentioned followings:}

1. Can you articulate arguments and claims against to claims stated in the boxes?

2. Which data you do use if you are able to generate counter arguments?

3. How do you justify your own claim, counter claim and-or counter argument?

4. Are there any conditions and-or scientific knowledge that support your claim, counter claim and-or counter argument?

5. Do you alter your initial claim, counter claim and-or counter argument which you generate in the line with $1^{\text {st }}$ question and how is it possible? 


\section{Appendix 2}

\section{Semi-structured Interview Questions}

1. When different points of view emerged in the argumentation process, did you manage to convince the group members of the validity of your perspective or was it the other way round?

Possibe probing questions:

- In general I convinced them (How could you do that?)

- In general my groups' members convinced me (How could they do that?)

2. Would you say that you could argue quite well about the issue of cloning?

Possibe probing questions:

- If the answer is -yes-; how your competence was reflected upon the argumentations regarding cloning; for instance could you carry the ground of discussion in alternative contexts?

- If the answer is -no-; what can be done to be a good arguer, what are your criteria?

3. Do you believe that you engage in argumentations more effectively if you consider a different discussion topic instead of cloning?

Possibe probing questions:

- $\quad$ For instance for which socio-scientific issue you suppose that you are able to engage in argumentation more elaborately?

- Can give any instances of the discussion topics that you would argue it better compare to cloning?

4. During the argumentation on cloning, did the arguments ever come to a standstill?

Possibe probing questions:

- What is the reason?

Did you do something to open up new areas to argue? 


\section{Bilimsel Argümantasyon Kalitesine Alan Bilgisinin Etkisi: KIonlama Bağlamı}

\section{Ali Yiğit Kutluca ${ }^{\dagger}$, Pınar Seda Çetin ve Nihal Doğan}

*Kastamonu Üniversitesi, Kastamonu, Türkiye

Abant İzzet Baysal Üniversitesi, Bolu, Türkiye

Makale Gönderme Tarihi: 06.09.2013

Makale Kabul Tarihi: 18.04.2014

Özet - Argümantasyon üst düzey düşünme becerilerini geliştirmede öğretmenlere önemli katkılar sağladığından ve öğrenci merkezli olmasından dolayı son yıllarda fen eğitimcileri tarafindan önem verilen konular arasında yer almaktadır. Bu nedenle; bu çalışmada alan bilgi seviyesiyle, bilimsel argümantasyon kalitesi arasındaki ilişki araştırılarak, fen ve teknoloji öğretmen adaylarına bilimsel argümantasyon becerisi kazandırılmaya çalışılmıştır. Veri toplama aracı olarak öğretmen adaylarına Lyngved (2009) tarafindan geliştirilen "Klonlama Kavramsal Anlama Testi," araştırmacılar tarafından Türkçeye çevrildikten sonra uygulanmıştır. Klonlama Kavramsal Anlama Testinin analiz sonuçlarına göre "alt-orta-üst" olarak gruplara ayrılan 54 fen ve teknoloji öğretmeni adayı (44 klz, 10 erkek), genetik klonlamayla ilgili senaryolar hakkında bilimsel argümantasyon sürecine dahil olmuşlardır. Her grubun oluşturduğu argümanlar; Erduran, Simon ve Osborne (2004) tarafindan geliştirilen analitik değerlendirme aracıyla analiz edilmiştir. Ayrıca öğretmen adaylarıyla, yarı yapılandırılmış görüşmeler yapılarak, alan bilgi seviyesiyle bilimsel argümantasyon kalitesi arasında gözlemlenen bulgular derinlemesine incelenmiştir. Araştırmanın sonuçlarına göre çalışmaya katılan öğretmen adaylarının sahip oldukları alan bilgi seviyesi ile bilimsel argümantasyon kaliteleri arasında anlamlı bir ilişki olmadığını tespit edilmiştir. Bundan sonraki çalışmalar alan bilgisi ve argüman kalitesi arasındaki ilişkiyi daha net anlamamız için farklı konularda ve daha büyük örneklemlerle gerçekleştirilebilir.

Anahtar kelimeler: Argümantasyon, bilimsel argümantasyon, alan bilgisi, klonlama.

DOI No: 10.12973/nefmed.2014.8.1.a1

\footnotetext{
${ }^{\dagger}$ İletişim: Ali Yiğit Kutluca, Eğitim Fakültesi, Kastamonu Üniversitesi, Kastamonu, Türkiye

E-mail: aliyigit8834@gmail.com
} 


\section{Genişletilmiş Özet}

Günümüzde çeşitli eğitim sistemlerinin odaklandığı en önemli olgulardan biri, bilimsel okuryazarlıktır. Bilimsel okuryazar bireyler, hızla gelişen bilimsel ve teknolojik değişimlere daha çabuk adapte olmaktadırlar. Öğrencilerin, bilim insanlarının çabalarını daha iyi anlamaları ve onların bilimsel bilgiyi elde etme aşamasında hangi bilimsel süreçlerden geçtiklerini fark etmeleri, bilim okur-yazarlığının kritik bir bileşeni olarak düşünülmektedir. $\mathrm{Bu}$ amaçları gerçekleştirme bilimsel argümantasyon önemli bir pedagojik araç olarak fen eğitiminde yerini almıştır (Erduran, 2007). Argümantasyon süreci; Kuhn'a (1993) göre; iki veya daha fazla bireyin, herhangi bir bilgiyi mantığa dayalı çelişkili iddialarla diyaloglu olarak tartışmasını içerir. Bricker ve Bell, (2008), fen eğitiminin hedefinin sadece öğrencileri bilimsel bilgi açısından uzmanlaştırmak değil, bilimsel tartışmalara katılmaya teşvik etmek olarak da belirtmişlerdir. Öğrencilerin geniş bir kavramsal anlayış elde edebilmeleri için tartışmalar sırasında fikirlerini açıkça belirtmeleri ve argümantasyon sürecinin içerisine dâhil olmaları gereklidir. Buna göre; öğrencilerin argümantasyon sürecine teşvik edilmesi öğretmenler tarafından sağlanmalıdır. Öğretmenlerin rolü; bireylere salt bilgiyi aktarmak değil, aynı zamanda onların bu bilgiyi nasıl ve nerede kullanacaklarına rehberlik etmek olmalıdır. Literatürde, bilimsel argümantasyon kalitesi ile alan bilgi seviyesi arasındaki olas1 ilişkiyi inceleyen çalışmalarda elde edilen sonuçlar; daha çok bu iki değişken arasında pozitif bir ilişkinin olduğunu öne sürmektedir (Sampson ve Clark, 2011; von Aufschnaiter, Erduran, Osborne ve Simon, 2008; Roychoudhury ve Rice, 2009). Yalnız, literatürdeki çalışmalar arasında bu konuya yönelik hâkim bir görüş birliği bulunmamakla birlikte, sonuçların nedenlerini belirtme anlamında da herhangi bir bulgunun verilmediği görülmektedir. Literatürün (Sadler, 2004; von Aufschnaiter, Erduran, Osborne ve Simon, 2008; Roychoudhury ve Rice, 2009) ortaya çıkardığı sonuçların çelişkili olması ve ulaşılan sonuçların nedenlerinin çok fazla araştırılmamış olması nedeniyle bu çalışmada fen ve teknoloji öğretmen adayları, genetik klonlama konusunda bilimsel argümantasyon-alan bilgi seviyesi arasındaki ilişkiyi ve bunun nedenlerini incelemek için argümantasyon süreçlerine dâhil edilmişlerdir. Özetle bu çalışma, özel olarak klonlama konusu hakkında bireylerin oluşturduğu bilimsel argüman kalitesinin, onların alan bilgisi seviyelerden nasıl etkilendiğinin incelenmesi ve ortaya çıkacak sonuçların bu alanda sınırlı olan alan yazına vereceği fikirler bakımından önemlilik arz etmektedir. 


\section{Metodoloji}

Çalışmanın örneklemini bir devlet üniversitesinin fen ve teknoloji öğretmenliği son sınıfında okuyan 54 (44 kız ve 10 erkek) öğretmen adayı oluşturmaktadır. Katılımcılar, "Klonlama Kavramsal Anlama Testi” analizine göre grup içi oldukça homojen, gruplar arası ise oldukça heterojen bir şekilde, alt-orta-üst olarak dörder kişilik üç gruba ayrılmıştır. Bunun ardından gruplarda bulunan katılımcılar da dahil olmak üzere tüm sınıf üyeleri, bilimsel senaryolar yardımıyla küçük grup tartışması yapmışlardır. Argümantasyon süreci sonrasında, her gruptan gönüllük esasıyla seçilen 1 kişi(12 kişinin \%25'i ölçüt alınmıştır) ile alan bilgisi ve argümantasyon kalitesi arasındaki olası ilişkinin nedenlerini tespit etmek için yarı yapılandırılmış görüşmeler yapılmıştır. Uygulama süreci toplamda 7 hafta sürmüştür.

İlgili literatürde bireylerin bilimsel argümantasyonlarının kalitesini belirlemek için Toulmin Argüman Modeli (1958)'ni temel alan çalışmalar yer almaktadır (JimenezAleixandre, Rodrigues ve Duschl, 2000; Erduran, Simon ve Osborne, 2004). Toulmin Argüman Modeli 1şı̆̆ında bireylerin bilimsel bağlamda oluşturdukları argümanları değerlendirilmesi amaciyla Erduran, Simon ve Osborne (2004) tarafindan geliştirilen metodolojik araç kullanılmıştır. Bu ölçeğe göre; bireyin oluşturduğu argümantasyon kalitesini belirleyen en önemli etken çürütme ve gerekçelerdir. Bu analitik ölçek birçok çalışmada uygulanmış ve bilimsel ve sosyobilimsel argümanların kalitelerini belirlemede fonksiyonel olduğu gözlemlenmiştir (Osborne, Erduran ve Simon, 2004). Argümantasyon süreci sonrasında her gruptan rastgele seçilen 1 kişi (alt, orta ve üst grupta toplam 12 kişi vardır. Toplam katılımcının en az \%25'i temel alınmıştır.) ile yapılan görüşmelerden gelen nitel veriler ise tümevarımcı içerik analizi yöntemi ile analiz edilmiştir. Grupların argümantasyon kalitelerini analiz etmek için yukarıda belirtilmiş olan 3 senaryo içerisinden "Sizin Fikriniz Nedir?" başlıklı senaryo seçilerek, analizler bu senaryo yardımıyla oluşturulan argümanlar üzerinden yapılmıştır. Bu senaryo, grup tartışmalarının diğerlerine oranla daha uzun olması ve bu sayede verilerin daha net görülebilir olması, katılımcıların süreç içerisindeki aktifliği ve katılımcıların tartışma için daha tecrübeli halde olması göz önünde bulundurularak seçilmiştir.

\section{Sonuç ve Tartışma}

Alan bilgi seviyesiyle bilimsel argümantasyon kalitesi arasındaki ilişkinin incelendiği bu araştırmada; çalışmaya katılan öğretmen adaylarının sahip oldukları alan bilgi seviyesi ile bilimsel argümantasyon kaliteleri arasında anlamlı bir ilişki olmadığını tespit edilmiştir. Bilimsel argümantasyon kalitesi ile alan bilgi seviyesi arasındaki ilişkiye yönelik elde edilen nitel ve nicel bulgular, grupların argümantasyon kalitesi arasında anlamlı bir farklılık olmasa 
da alt grubun diğer iki gruba göre daha kaliteli argümanlar ürettiğini göstermektedir. Öğretmen adaylarının bilimsel argümantasyon sürecinde oluşturdukları argümanlara nitel anlamda bakıldığında; alt gruptan üst gruba doğru gidildikçe argümantasyon kalitesinde net olmayan azalmalar gözlenmiştir. Çalışmanın nitel bulguları; bilimsel argümantasyon ile alan bilgi seviyesi arasındaki ilişkinin net olmaması, alan bilgisi dışında bireylerin oluşturdukları argümanların kalitesini etkileyen farklı etkenlerin (tecrübe, kişisel deneyimler, sosyodemografik özellikler vb.) de bulunuyor olabileceğini göstermiştir. Son olarak görüşmelerde tüm bireyler, daha çok ilgi duyulan konularda daha iyi bir argümantasyon sürecinin geçirileceğini öne sürmüşlerdir. Öğretmen adaylarının görüşme sorularına verdikleri yanıtlar çalışmada ulaşılan sonuçların "argümantasyon becerisi, odaklanma, tecrübeler, sosyal etkileşim, bulunulan çevre ve argümantasyon doğasına bă̆lı kalma" gibi etmenlerden kaynaklanabileceğini göstermiştir. 